\title{
Article \\ Purification of Industrial Copper Electrolyte from Bismuth Impurity
}

\author{
Patrycja Kowalik*D, Dorota Kopyto, Mateusz Ciszewski ${ }^{(D}$, Michał Drzazga (D) and \\ Katarzyna Leszczyńska-Sejda (D)
}

Łukasiewicz Research Network-Institute of Non-Ferrous Metals, Sowińskiego 5, 44-100 Gliwice, Poland; dorotak@imn.gliwice.pl (D.K.); mateuszc@imn.gliwice.pl (M.C.); michald@imn.gliwice.pl (M.D.); kasial@imn.gliwice.pl (K.L.-S.)

* Correspondence: patrycjak@imn.gliwice.pl; Tel.: +48-32-2380-287

Citation: Kowalik, P.; Kopyto, D. Ciszewski, M.; Drzazga, M.;

Leszczyńska-Sejda, K. Purification of Industrial Copper Electrolyte from

Bismuth Impurity. Minerals 2022, 12,

36. https://doi.org/10.3390/

$\min 12010036$

Academic Editors: Elsayed Oraby and Huan Li

Received: 24 November 2021

Accepted: 24 December 2021

Published: 26 December 2021

Publisher's Note: MDPI stays neutral with regard to jurisdictional claims in published maps and institutional affiliations.

Copyright: (c) 2021 by the authors Licensee MDPI, Basel, Switzerland. This article is an open access article distributed under the terms and conditions of the Creative Commons Attribution (CC BY) license (https:// creativecommons.org/licenses/by/ $4.0 /)$.

\begin{abstract}
This work focused on purifying copper electrolytes from a bismuth impurity on a laboratory scale. The electrolyte came from Polish copper electrorefineries with the content of main components, $\mathrm{g} / \mathrm{dm}^{3}: 49.6 \mathrm{Cu}, 160 \mathrm{H}_{2} \mathrm{SO}_{4}$. The electrolyte was enriched in bismuth by $\mathrm{Bi}_{2} \mathrm{O}_{3}$ addition. Purification of bismuth contamination was carried out using selected agents with adsorbing effects, such as barium hydroxide octahydrate, strontium carbonate, barium carbonate, barium and lead sulfates. The trials were performed until achieving the Bi level-below $0.1 \mathrm{~g} / \mathrm{dm}^{3}$. During the experiments, it was noticed that electrolyte purification degree depends on initial Bi concentration in electrolyte, time and temperature, as well as on the type and amount of the bismuth-lowering agent. The most satisfactory results of Bi impurity removal were with additions of barium hydroxide octahydrate, strontium carbonate and barium carbonate to electrolyte at $60^{\circ} \mathrm{C}$ for $1 \mathrm{~h}$. These parameters revealed the highest electrolyte purification degree. Bismuth is not removed effectively from electrolytes by barium sulfate or lead sulfate addition. The efficiency of the purification process is much higher when the agents are added to the solution in the form of carbonates or hydroxides. Extending the electrolyte purification process time may cause dissolution of bismuth from the resulting precipitate and increase of bismuth concentration in electrolytes.
\end{abstract}

Keywords: bismuth; solution purification; copper electrolyte; electrorefining; impurities; copper metallurgy

\section{Introduction}

Bismuth is one of the most problematic impurities in copper electrorefining. Its elevated concentration in the electrolyte can contribute to contamination of the produced copper cathode, so the bismuth level in the electrolyte must be controlled [1,2]. Due to this, part of the electrolyte is periodically withdrawn from circulation circuits in order to reduce the bismuth and other element concentrations $[1,3,4]$. The literature data show that bismuth electrolyte concentrations below $\sim 0.1 \mathrm{~g} / \mathrm{dm}^{3}$ have no negative impact on the produced copper cathode in the electrorefining process, and bismuth will not interfere with the electrolysis [5].

Moreover, in many publications, techniques of copper electrolyte purification from impurities have been proposed, also due to increased Bi content [1,6]. These methods include: ion exchange using selected ion exchange resins (Unicellex UR-3300, Duolite C-467, Lewatit TP 260) [1,7-9], solvent extraction using selected extractants (DEHPA, MEHPA, Kelex 100, DS 5834, LIX 1104, REX-1, REX-2, TDA) [1,10-13], molecular recognition technology (MRT) using specially designed organic chelating agents or ligands [14-19]. Many refineries utilize anode doping and electrolyte additions. For example, arsenic is used in refineries as the primary control technique for $\mathrm{Bi}$ and $\mathrm{Sb}$ [1,20-22]. There are several studies on using the various types of substances with an adsorbing effect on selected pollutants, including Bi. These adsorbents are activated carbon, zeolites, silica gel, stannic 
acid or sulfates (barium, strontium, lead) [1,23-28]. Despite the many advantages of these industrial methods, they also have a number of disadvantages. For example, the liberator processing has high energy consumption, generates hazardous gas and copper concentrations must be greatly reduced. Anode doping can lead to the entrainment of impurities to the copper cathode and to anode slimes. In the case of solvent extraction, problems appear with organics, which may contaminate electrolytes by strip or regeneration chemicals. The use of activated carbon in the purification process lowers kinetics and loading capacity. Additionally, carbon cannot be re-used. Molecular recognition technology is mainly used for bismuth extraction, but resins are very expensive. Whereas the ion exchange resin can be poisoned, the lose efficiency often requires the use of $\mathrm{HCl}$ for elution. It is also necessary to choose a suitable ion exchange resin, which will be selective to the selected pollutant [1-3,16-19]. The disadvantages of these methods may be the reason for the growing interest of the scientific world in extending understanding of the purification methods examined in this article.

The method of copper electrolyte purification described in Hyvärinen patent [5] focuses on bismuth and antimony removing from electrolyte using poorly soluble sulfates: barium, strontium or lead, which are added to the solution in the form of either sulfate salts or carbonates. The forming precipitate is separated by filtration, and the clarified electrolyte is returned to the circulation of the copper electrolysis. Despite satisfactory results, this method has never been introduced into industrial practice.

Therefore, the aim of this research is to purify industrial copper electrolytes from bismuth impurities below $0.1 \mathrm{~g} / \mathrm{dm}^{3}$, using selected compounds with adsorbing effects, such as barium hydroxide octahydrate, strontium carbonate, barium carbonate, barium sulfate and lead sulfate. The tests used industrial electrolytes from domestic copper electrorefineries. The dependence of electrolyte purification degree from bismuth impurity on the initial concentration of bismuth in electrolyte, time, temperature and selected bismuth removal agent were investigated. The tests were conducted using a temperature range of $20-60^{\circ} \mathrm{C}$ and a processing time of 1 to $6 \mathrm{~h}$. Furthermore, bismuth(III) oxide was used for increasing $\mathrm{Bi}$ concentration in electrolytes.

\section{Materials and Methods}

The experiments were carried out using industrial electrolyte (S1) from Polish copper electrorefineries. Its composition is presented in Table 1.

Table 1. Composition of industrial copper electrolyte used in tests.

\begin{tabular}{cccccccc}
\hline \multicolumn{7}{c}{ Composition S1, $\mathbf{g} / \mathbf{d m}^{\mathbf{3}}$} \\
\hline $\mathrm{Cu}$ & $\mathrm{H}_{2} \mathrm{SO}_{4}$ & $\mathrm{Bi}$ & $\mathrm{As}$ & $\mathrm{Sb}$ & $\mathrm{Ni}$ & $\mathrm{Fe}$ & $\mathrm{Ca}$ \\
49.60 & 160.00 & 0.0294 & 5.75 & 0.17 & 5.40 & 0.12 & 0.38 \\
\hline
\end{tabular}

Additionally, electrolytes (S2, S3, S4) with increased bismuth content were also prepared for the tests (Figure 1). The procedure for preparation of S2, S3, S4 solutions involves introducing the calculated weight of bismuth(III) oxide into industrial copper electrolyteS1. Due to very poor solubility, this reagent was added into the electrolyte with $15 \%$ excess. After introducing bismuth(III) oxide weight, solutions were heated to $60{ }^{\circ} \mathrm{C}$ and intensively stirred for $4 \mathrm{~h}$. After this time, they were cooled, filtered and separated from undissolved residue. 


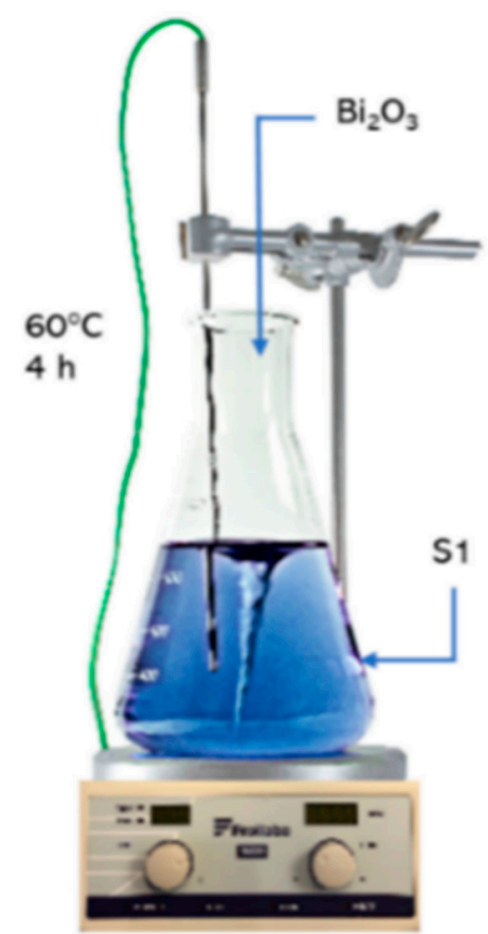

Figure 1. Procedure for preparation of S2, S3, S4 electrolytes.

The results of Bi concentration after bismuth(III) oxide addition to the industrial copper electrolyte (S1) are reported in Table 2.

Table 2. Composition of S2, S3, S4 electrolytes used in tests.

\begin{tabular}{ccc}
\hline \multirow{2}{*}{ Electrolyte } & \multicolumn{2}{c}{ Bi Concentration, $\mathbf{g} / \mathbf{d m}^{\mathbf{3}}$} \\
& Assumed Value & Real Value \\
\hline S2 & 0.2 & 0.177 \\
S3 & 0.3 & 0.269 \\
S4 & 0.4 & 0.370 \\
\hline
\end{tabular}

The analyses were performed by the Łukasiewicz Research Network-Institute of Non-Ferrous Metals, the Centre of Analytical Chemistry (Gliwice, Poland). The determination of Bi concentration was carried out using two techniques: flame atomic absorption spectroscopy (FAAS; SOLAAR S4, Thermo, Waltham, MA, USA) in the range of 0.050-0.500 g/ $\mathrm{dm}^{3}$ and inductively coupled plasma mass spectrometry (ICP-MS; NexION 300D, PerkinElmer, Waltham, MA, USA) in the range of $0.0001-0.500 \mathrm{~g} / \mathrm{dm}^{3}$.

Tests for lowering Bi content from S2, S3, S4 electrolytes were carried out using selected agents, i.e., barium hydroxide octahydrate ( $>98 \%$, Acros Organics, Antwerp, Belgium), strontium carbonate ( $\geq 98 \%$, Sigma-Aldrich, St. Louis, MO, USA), barium carbonate (99\%, Acros Organics, Antwerp, Belgium), barium sulfate (97\%, Alfa Aesar, Stoughton, MA, USA) and lead sulfate (99\%, Acros Organics, Antwerp, Belgium). Experiments were conducted in the temperature range $20-60{ }^{\circ} \mathrm{C}$, during 1-6 h, with varying amounts of selected agents $2-16 \mathrm{~g} / \mathrm{dm}^{3}$ and with different initial Bi concentrations in an electrolyte. The trials were performed in duplicate. At the end of each process, solutions were cooled and filtered, and the Bi concentration was analyzed. Electrolyte purification degree was calculated based on analysis of bismuth concentration before and after the purification process. The initial concentration of bismuth in electrolytes, which was directed to the purification process, was taken as $100 \%$. The purification process was carried out until achieving the Bi concentration below $0.1 \mathrm{~g} / \mathrm{dm}^{3}$. 


\section{Results and Discussion}

3.1. Dependence of Electrolyte Purification Degree on Type and Amount of Bi Removal Agent Used

In these experiments, $\mathrm{S} 4$ electrolytes (initial Bi concentration $-0.370 \mathrm{~g} / \mathrm{dm}^{3}$ ) were used. The tests were carried out for $1 \mathrm{~h}$ at $60^{\circ} \mathrm{C}$. This temperature was selected for the first trials due to the fact that the electrolyte temperature in the copper electrorefining process is about $60^{\circ} \mathrm{C}$. The effect of selected agents (type and dose) on Bi concentration in electrolyte and on electrolyte purification degree is presented in Figure 2.

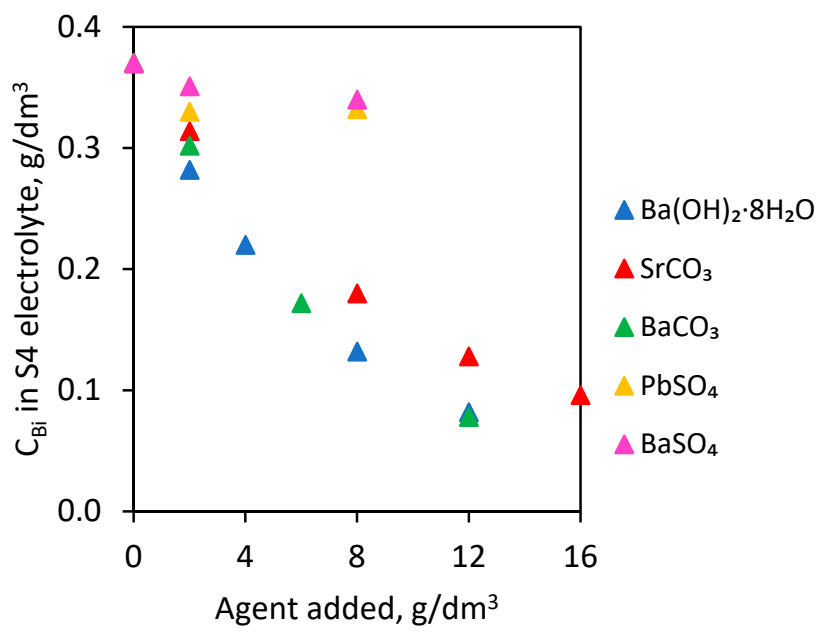

(a)

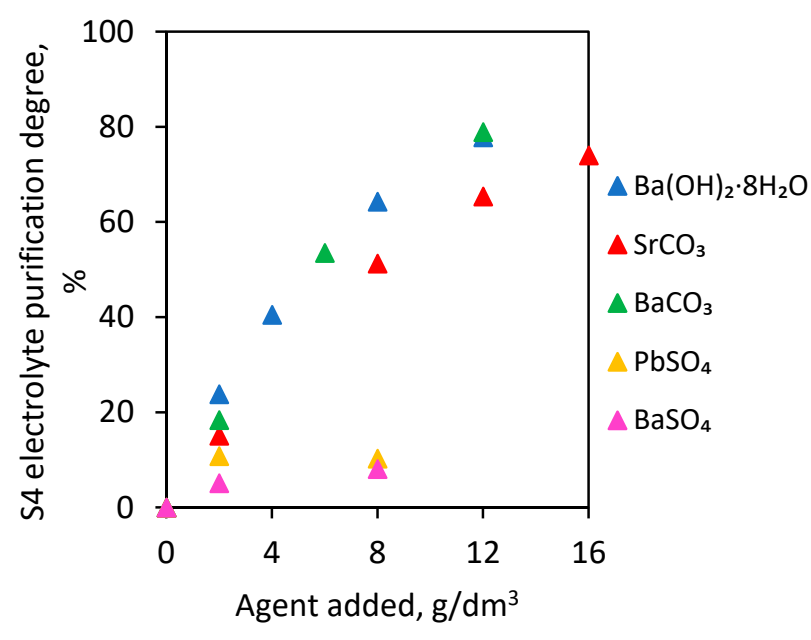

(b)

Figure 2. Barium hydroxide octahydrate, strontium carbonate, barium carbonate, barium sulfate and lead sulfate addition on (a) Bi concentration in S4 electrolyte and (b) S4 electrolyte purification degree.

The addition of $12.0 \mathrm{~g} / \mathrm{dm}^{3}$ barium hydroxide octahydrate, $16.0 \mathrm{~g} / \mathrm{dm}^{3}$ strontium carbonate or $12.0 \mathrm{~g} / \mathrm{dm}^{3}$ barium carbonate to the $\mathrm{S} 4$ electrolyte caused a reduction of $\mathrm{Bi}$ concentration below $0.1 \mathrm{~g} / \mathrm{dm}^{3}$. The initial Bi value- $0.370 \mathrm{~g} / \mathrm{dm}^{3}$ in the S4 electrolyte was reduced to $0.082,0.096$ and $0.078 \mathrm{~g} / \mathrm{dm}^{3}$, respectively. For these doses, the electrolyte purification degree was $77.8 \%$ for barium hydroxide octahydrate, $74.0 \%$ for strontium carbonate and $78.9 \%$ for barium carbonate.

However, the addition of both barium and lead sulfate to the $\mathrm{S} 4$ electrolyte at $60{ }^{\circ} \mathrm{C}$ practically did not cause any reduction in the Bi amount. Furthermore, increasing doses of these compounds did not purify electrolytes from Bi contamination. The highest dose$8.0 \mathrm{~g} / \mathrm{dm}^{3}$ of barium sulfate and $8.0 \mathrm{~g} / \mathrm{dm}^{3}$ lead sulfate added to $S 4$ electrolyte induced only slightly decreases in Bi concentrations to 0.340 and $0.332 \mathrm{~g} / \mathrm{dm}^{3}$. Electrolyte purification degrees were only $8.1 \%$ and $10.3 \%$, respectively.

At $60^{\circ} \mathrm{C}$, it is possible to purify copper electrolyte from bismuth impurity, using barium hydroxide octahydrate, strontium carbonate and barium carbonate. This temperature revealed the most satisfactory results and the highest electrolyte purification degree in the case of these three added agents.

The conducted experiments showed that the addition of agents in the form of sulfates to the copper electrolyte did not reduce the bismuth concentration. The compounds introduced as sulfates (both barium and lead sulfate) did not allow the formation of new sulfate precipitates, which co-precipitated appropriate impurities in the electrolyte. The efficiency of the purification process was much higher when the agents were added to the solution in the form of carbonates or hydroxides, such as barium hydroxide octahydrate, strontium carbonate, barium carbonate. These compounds undergo electrolytic dissociation under the influence of acid in the electrolyte, and then the forming sulfate precipitate (barium or strontium) co-precipitates the bismuth and part of the antimony.

Thus, the electrolyte purifying from Bi contamination depends on the type and amount of removal agent added. In the case of barium hydroxide octahydrate, strontium carbonate 
and barium carbonate additions, the results with similar values were obtained. In order to better interpret them, the number of grams of Bi removed by $1 \mathrm{~g}$ of Ba or Sr ions was calculated. This value was called the "purification efficiency". The calculated amount of Bi removed in grams per $1 \mathrm{~g}$ of $\mathrm{Ba}$ or $\mathrm{Sr}$ ions (purification efficiency) depending on type and amount of agent added into electrolyte is shown in Table 3 and in Figure 3.

Table 3. Bi amount removed in grams per $1 \mathrm{~g}$ Ba or Sr ions (purification efficiency) depending on the type and amount of agent added into $\mathrm{S} 4$ electrolyte.

\begin{tabular}{|c|c|c|c|c|c|c|}
\hline \multirow[b]{2}{*}{$\begin{array}{l}\text { Agent } \\
\text { Added, } \\
\text { g/dm }{ }^{3}\end{array}$} & \multicolumn{2}{|c|}{$\mathrm{Ba}(\mathrm{OH})_{2} \cdot 8 \mathrm{H}_{2} \mathrm{O}$} & \multicolumn{2}{|c|}{$\mathrm{SrCO}_{3}$} & \multicolumn{2}{|c|}{$\mathrm{BaCO}_{3}$} \\
\hline & $\begin{array}{c}\text { Ba ions } \\
\text { Amount, g }\end{array}$ & $\begin{array}{l}\text { Purification } \\
\text { Efficiency, } \\
\text { g Bi/1 g Ba }\end{array}$ & $\begin{array}{c}\text { Sr Ions } \\
\text { Amount, g }\end{array}$ & $\begin{array}{l}\text { Purification } \\
\text { Efficiency, } \\
\text { g Bi/1 g Sr }\end{array}$ & $\begin{array}{l}\text { Ba Ions } \\
\text { Amount, } g\end{array}$ & $\begin{array}{l}\text { Purification } \\
\text { Efficiency, } \\
\text { g Bi/1 g Ba }\end{array}$ \\
\hline 2 & 0.87 & 0.101 & 1.19 & 0.047 & 1.39 & 0.049 \\
\hline 8 & 3.48 & 0.068 & 4.75 & 0.040 & - & - \\
\hline 12 & 5.22 & 0.055 & 7.12 & 0.034 & 8.35 & 0.035 \\
\hline 16 & 6.96 & 0.046 & 9.50 & 0.028 & - & - \\
\hline
\end{tabular}

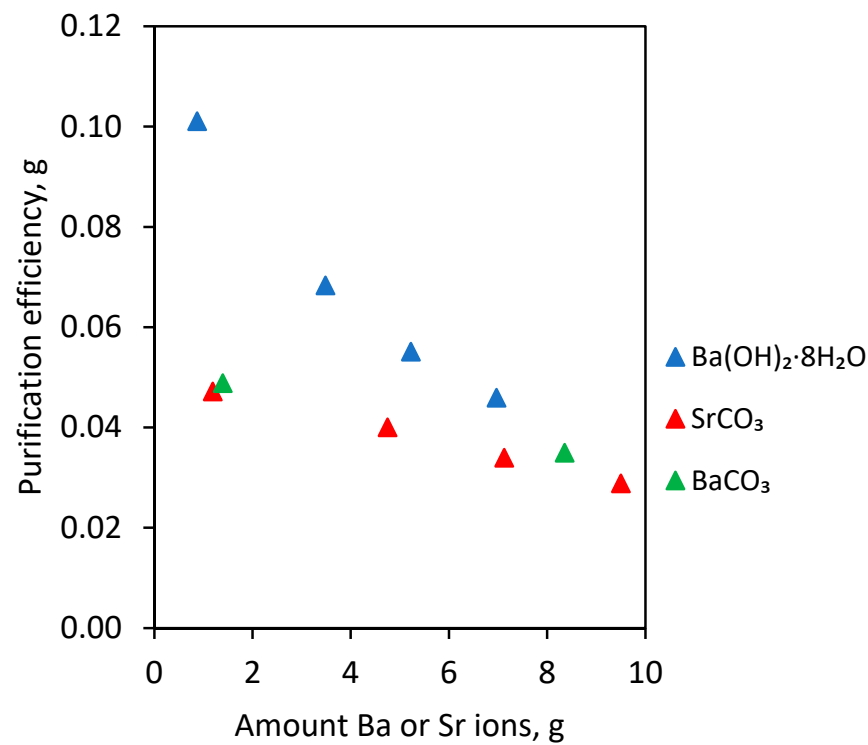

Figure 3. Bi amount removed in grams per $1 \mathrm{~g}$ Ba or Sr ions (purification efficiency) depending on the type and amount of agent added into S4 electrolyte.

On the basis of the results presented in Figure 3 and in Table 3, it can be seen that the highest purification efficiency was obtained using barium hydroxide octahydrate. For instance, in the case of $2 \mathrm{~g} / \mathrm{dm}^{3}$ barium hydroxide octahydrate addition to the electrolyte, it was possible to remove $0.101 \mathrm{~g}$ Bi. For the remaining two agents, the values of purification efficiency were lower but at a very similar level to each other.

Additionally, the analysis of antimony behavior in the purification processes was carried out. The antimony concentration was reduced below $0.12 \mathrm{~g} / \mathrm{dm}^{3}$ after barium hydroxide octahydrate, strontium carbonate and also barium carbonate additions. The introduction of these agents into the electrolyte enables the reduction of bismuth and antimony concentration in the copper electrolyte.

Based on the first experiments, it was shown that barium hydroxide octahydrate, strontium carbonate and barium carbonate enable purifying industrial copper electrolytes from bismuth contamination below $0.1 \mathrm{~g} / \mathrm{dm}^{3}$. The efficiency of the purification process is much higher when the agents are added to the solution in the form of carbonates or hydroxides. Unfortunately, the remaining compounds in the form of sulfates (barium sulfate and lead sulfate) did not remove the bismuth impurity from copper electrolytes. In 
the literature, it was found that the effectiveness of the purification process is improved if agents are added to the electrolyte in the form of carbonates, which decompose under the effect of the acid of the electrolyte, and thus no excess ions are left in the electrolyte [5].

\subsection{Dependence of Electrolyte Purification Degree from Bi Contamination on Time and Temperature}

In the subsequent laboratory experiments, S3 electrolytes (initial Bi concentration$0.269 \mathrm{~g} / \mathrm{dm}^{3}$ ) were used. The purification process of electrolytes from Bi contamination was carried out using two selected agents: barium hydroxide octahydrate and strontium carbonate. The experiments were conducted with 2 and $8 \mathrm{~g} / \mathrm{dm}^{3}$ doses of these additives at 20,30 and $60{ }^{\circ} \mathrm{C}$ for 1,3 and $6 \mathrm{~h}$. Figure 4 shows the dependence of Bi concentration on process time in $20^{\circ} \mathrm{C}$ (Figure $4 \mathrm{a}$ ), $30^{\circ} \mathrm{C}$ (Figure $4 \mathrm{~b}$ ), $60^{\circ} \mathrm{C}$ (Figure $4 \mathrm{c}$ ) with the addition of barium hydroxide octahydrate and strontium carbonate.

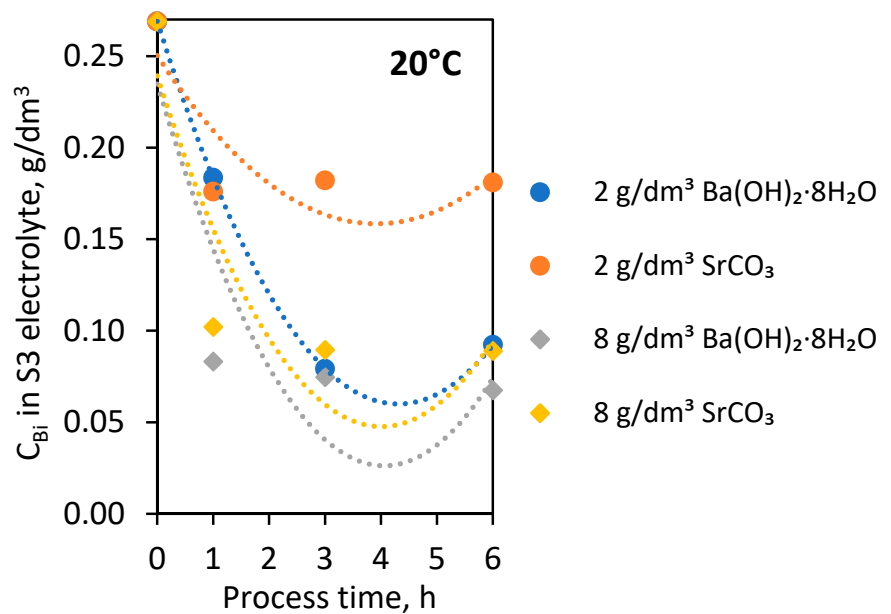

(a)

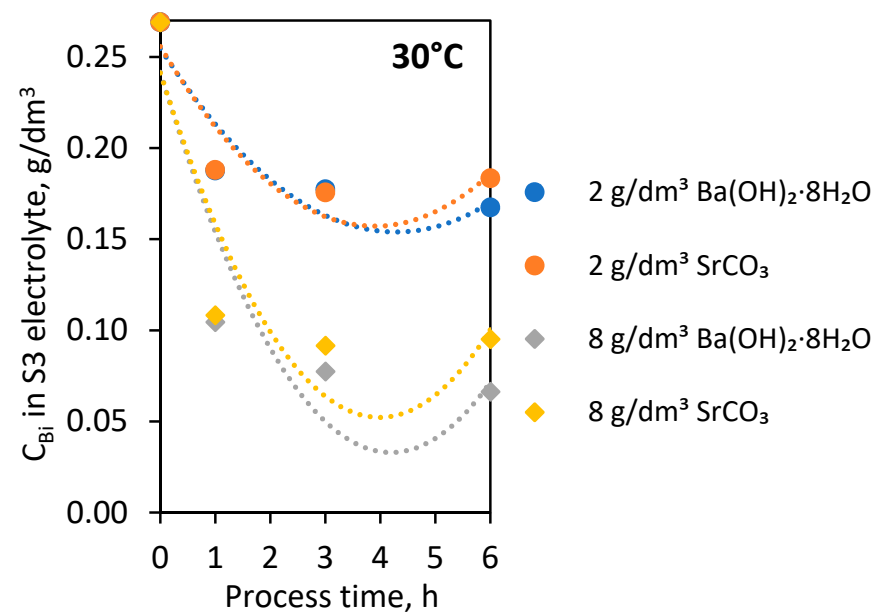

(b)

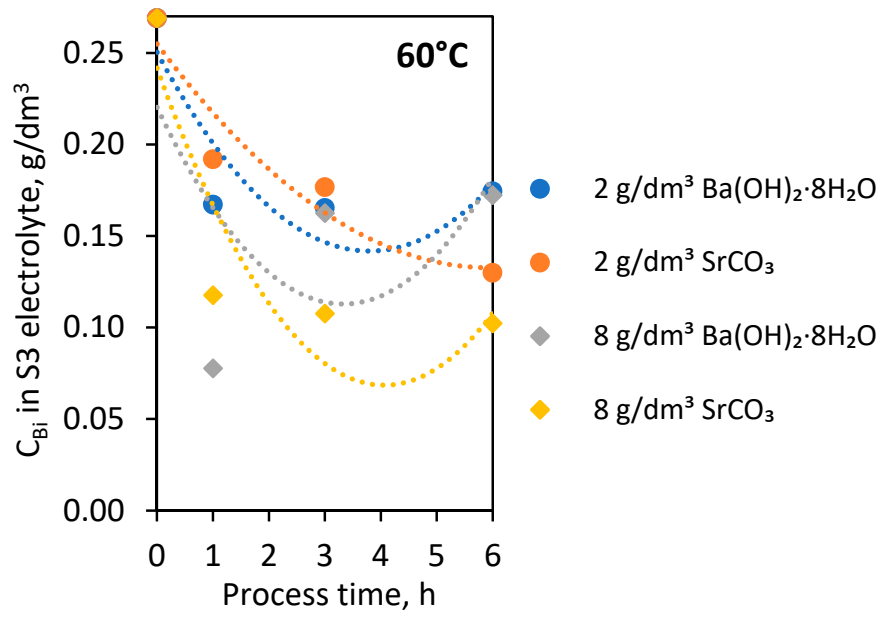

(c)

Figure 4. Dependence of Bi concentration in S3 electrolyte on process time with barium hydroxide octahydrate and strontium carbonate in (a) $20^{\circ} \mathrm{C}$; (b) $30^{\circ} \mathrm{C}$; (c) $60^{\circ} \mathrm{C}$.

After the first hour of the process, the Bi concentration dropped to below $0.2 \mathrm{~g} / \mathrm{dm}^{3}$, regardless of process temperature and type of agent used. The addition of $2 \mathrm{~g} / \mathrm{dm}^{3}$ of both barium hydroxide octahydrate and strontium carbonate to the S3 electrolyte caused lower purification of the solution from the Bi impurity than in the case of $8 \mathrm{~g} / \mathrm{dm}^{3}$.

At $20^{\circ} \mathrm{C}$, the addition of $8 \mathrm{~g} / \mathrm{dm}^{3}$ of both agents with extending process time to 3 and $6 \mathrm{~h}$ did not result in a further purification of the S3 electrolyte. The exception is the process 
carried out at $20{ }^{\circ} \mathrm{C}$ with $2 \mathrm{~g} / \mathrm{dm}^{3}$ barium hydroxide octahydrate, where the extension of process time caused a significant removal of Bi ions in the $\mathrm{S} 3$ electrolyte below $0.1 \mathrm{~g} / \mathrm{dm}^{3}$.

The results of purification at $30^{\circ} \mathrm{C}$ by barium hydroxide octahydrate and strontium carbonate were very similar. The addition of both additives $\left(2 \mathrm{~g} / \mathrm{dm}^{3}\right)$ at $30^{\circ} \mathrm{C}$ resulted in reducing Bi concentration to the levels 0.17 and $0.18 \mathrm{~g} / \mathrm{dm}^{3}$. Similarly, in the case of $8 \mathrm{~g} / \mathrm{dm}^{3}$ at $30{ }^{\circ} \mathrm{C}$ - successful purification to the Bi level below $0.1 \mathrm{~g} / \mathrm{dm}^{3}\left(0.0663 \mathrm{~g} / \mathrm{dm}^{3}\right.$ and $\left.0.0951 \mathrm{~g} / \mathrm{dm}^{3}\right)$.

Strontium carbonate addition to the $\mathrm{S} 3$ electrolyte at $60^{\circ} \mathrm{C}$ affected the rapid $\mathrm{Bi}$ ion removal after $1 \mathrm{~h}$ of the purification process. Then, gradually, a slight reduction of $\mathrm{Bi}$ concentration after 3 and $6 \mathrm{~h}$ was observed. In the case of barium hydroxide octahydrate introduced into the $\mathrm{S} 3$ electrolyte at $60^{\circ} \mathrm{C}$, the reverse effect was noticed. Extension of the processing time caused the increase of Bi concentration from $0.0778 \mathrm{~g} / \mathrm{dm}^{3}$, achieved after $1 \mathrm{~h}$, to $0.1626 \mathrm{~g} / \mathrm{dm}^{3}$ after $3 \mathrm{~h}$ and to $0.1724 \mathrm{~g} / \mathrm{dm}^{3}$ after $6 \mathrm{~h}$ of the process.

The results of the $\mathrm{S} 3$ electrolyte purification degree from process time and temperature for $2 \mathrm{~g} / \mathrm{dm}^{3}$ of both agent additives are presented in Figure $5 \mathrm{a}$ and for $8 \mathrm{~g} / \mathrm{dm}^{3}$ in Figure $5 \mathrm{~b}$.

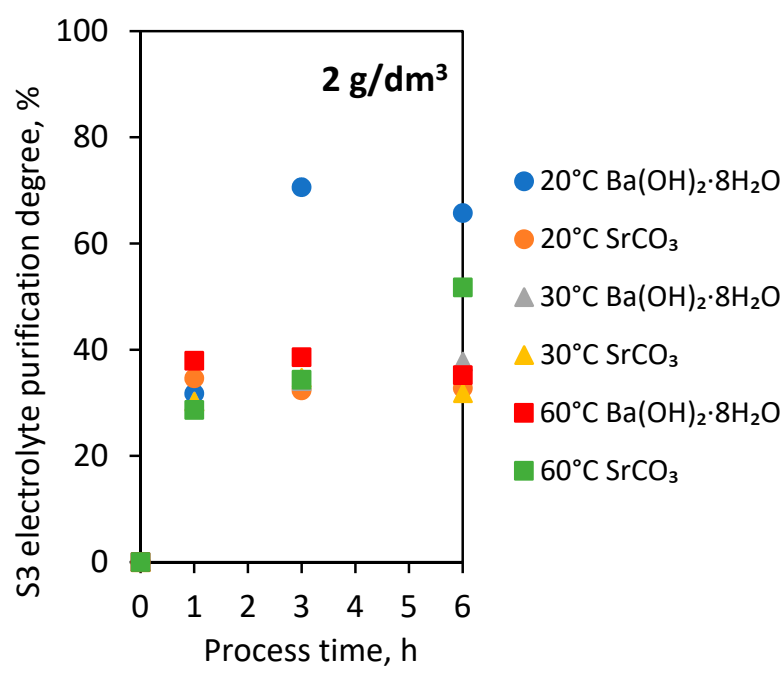

(a)

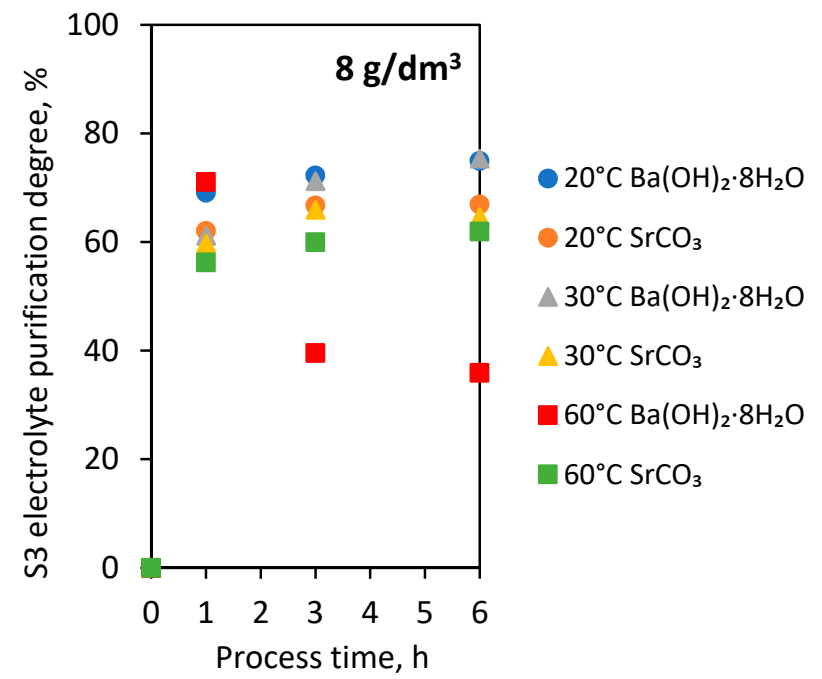

(b)

Figure 5. S3 electrolyte purification degree from process time and temperature with the addition of barium hydroxide octahydrate and strontium carbonate in the amounts (a) $2 \mathrm{~g} / \mathrm{dm}^{3}$; (b) $8 \mathrm{~g} / \mathrm{dm}^{3}$.

The electrolyte purification degrees were higher with the $8 \mathrm{~g} / \mathrm{dm}^{3}$ addition of both barium hydroxide octahydrate and strontium carbonate relative to the $2 \mathrm{~g} / \mathrm{dm}^{3}$ additives.

Depending on the temperature, the $2 \mathrm{~g} / \mathrm{dm}^{3}$ addition of both agents to the $\mathrm{S} 3 \mathrm{elec}-$ trolyte resulted in receiving the purification degree in the range of 28.6 to $37.9 \%$. Extending the processing time to 3 and $6 \mathrm{~h}$ did not significantly change the values of electrolyte purification degree. The exception was the process carried out at $20{ }^{\circ} \mathrm{C}$ with $2 \mathrm{~g} / \mathrm{dm}^{3}$ barium hydroxide octahydrate. In that case, the extension of the processing time to 3 and $6 \mathrm{~h}$ caused a significant growth of the S3 electrolyte purification degree to 65.7 and $70.6 \%$.

The experiments with $8 \mathrm{~g} / \mathrm{dm}^{3}$ addition of barium hydroxide octahydrate and strontium carbonate resulted in the growth of electrolyte purification degree with extending process time. Only in the experiment at $60^{\circ} \mathrm{C}$ was it observed to reduce the purification degree with extended processing time.

Extending the electrolyte purification process time may also cause dissolution of bismuth from the resulting precipitate and an increase of bismuth concentration in the electrolyte.

The values of S3 electrolyte purification degree in trials with $8 \mathrm{~g} / \mathrm{dm}^{3}$ barium hydroxide octahydrate and strontium carbonate additions during 1,3 and $6 \mathrm{~h}$ are presented in Table 4. 
Table 4. Electrolyte purification degree with $8 \mathrm{~g} / \mathrm{dm}^{3}$ addition of barium hydroxide octahydrate and strontium carbonate.

\begin{tabular}{|c|c|c|c|}
\hline \multirow{2}{*}{ Temperature, ${ }^{\circ} \mathrm{C}$} & \multirow{2}{*}{ Time, h } & \multicolumn{2}{|c|}{ S3 Electrolyte Purification Degree, \% } \\
\hline & & $8 \mathrm{~g} / \mathrm{dm}^{3} \mathrm{Ba}(\mathrm{OH})_{2} \cdot 8 \mathrm{H}_{2} \mathrm{O}$ & $8 \mathrm{~g} / \mathrm{dm}^{3} \mathrm{SrCO}_{3}$ \\
\hline \multirow{3}{*}{20} & 1 & 69.1 & 62.0 \\
\hline & 3 & 72.3 & 66.7 \\
\hline & 6 & 74.9 & 66.9 \\
\hline \multirow{3}{*}{30} & 1 & 61.2 & 59.7 \\
\hline & 3 & 71.2 & 65.9 \\
\hline & 6 & 75.4 & 64.7 \\
\hline \multirow{3}{*}{60} & 1 & 71.1 & 56.3 \\
\hline & 3 & 39.6 & 59.9 \\
\hline & 6 & 35.9 & 61.9 \\
\hline
\end{tabular}

On the basis of these trials, it was found that there is a possibility of achieving a safe, required and assumed level of bismuth concentration (below $0.1 \mathrm{~g} / \mathrm{dm}^{3}$ ) with appropriate parameters of the purification process. It was necessary to use increased doses of both applied agents, i.e., $8.0 \mathrm{~g} / \mathrm{dm}^{3}$ to S3 electrolytes (initial Bi concentration $-0.269 \mathrm{~g} / \mathrm{dm}^{3}$ ). The exception in these experiments is also the test carried out at $20^{\circ} \mathrm{C}$ with extended processing time and the addition of $2 \mathrm{~g} / \mathrm{dm}^{3}$ barium hydroxide octahydrate to the electrolyte.

\subsection{Dependence of Electrolyte Purification Degree from Bi Contamination on Initial Bi Concentration in Solution}

The last laboratory experiments were conducted using S2, S3 and S4 electrolytes. In order to purify them from Bi ions, the various amounts from 2 to $12 \mathrm{~g} / \mathrm{dm}^{3}$ barium hydroxide octahydrate were introduced at $60^{\circ} \mathrm{C}$ for $1 \mathrm{~h}$. The dependence of Bi concentration in the electrolyte on initial Bi concentration $\left(0.177,0.269,0.370 \mathrm{~g} / \mathrm{dm}^{3}\right)$ and the amount of barium hydroxide octahydrate added are presented in Figure 6a. The dependence of electrolyte purification degree on initial Bi concentration $\left(0.177,0.269,0.370 \mathrm{~g} / \mathrm{dm}^{3}\right)$ and amount of barium hydroxide octahydrate added are shown in Figure $6 \mathrm{~b}$.

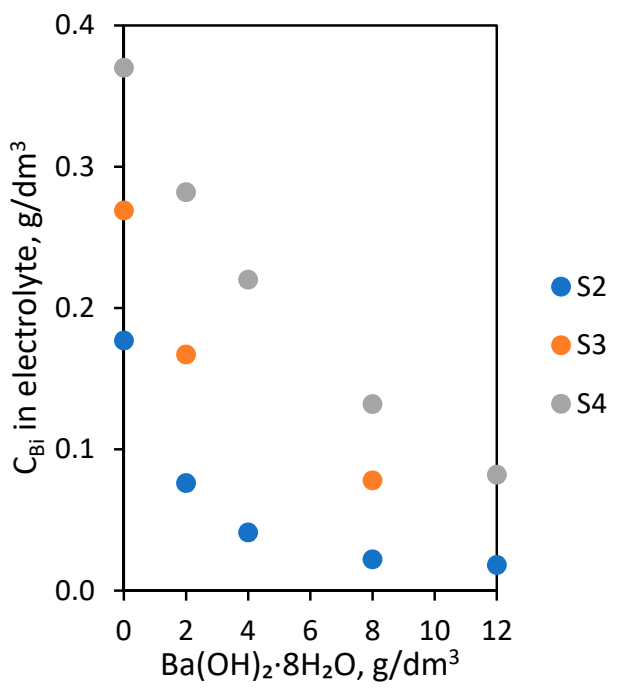

(a)

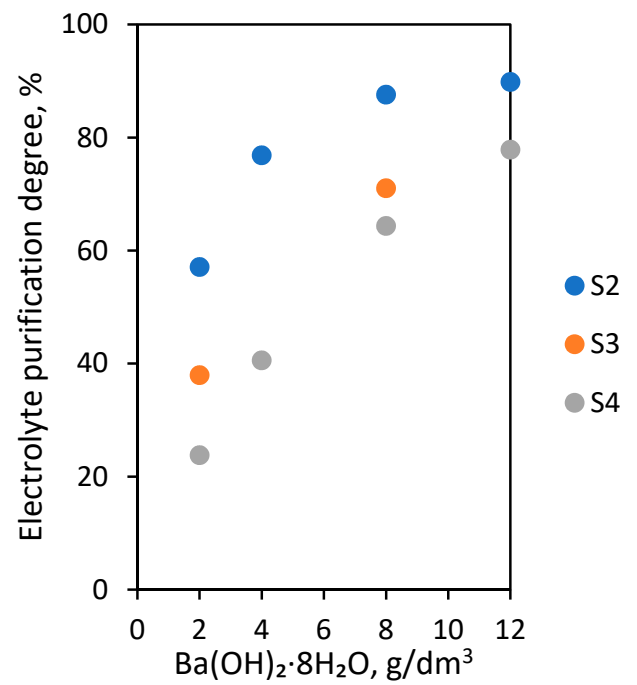

(b)

Figure 6. Dependence of initial Bi concentration $\left(0.177,0.269,0.370 \mathrm{~g} / \mathrm{dm}^{3}\right)$ and amount of barium hydroxide octahydrate added on (a) Bi concentration in electrolyte; (b) electrolyte purification degree. 
The obtained results show that with increased barium hydroxide octahydrate amounts added to electrolytes, the Bi concentration decreases proportionally below $0.1 \mathrm{~g} / \mathrm{dm}^{3}$. For the S4 electrolyte (with the highest initial Bi concentration- $-0.370 \mathrm{~g} / \mathrm{dm}^{3}$ ), it was possible to lower the Bi contamination to a level of $0.082 \mathrm{~g} / \mathrm{dm}^{3}$ after the introduction of $12 \mathrm{~g} / \mathrm{dm}^{3}$ of the agent. This is equivalent to a $77.8 \%$ S4 electrolyte purification degree. In the S3 electrolyte $\left(0.269 \mathrm{~g} / \mathrm{dm}^{3}\right)$, the addition of $8.0 \mathrm{~g} / \mathrm{dm}^{3}$ barium hydroxide octahydrate caused the removal of Bi ions below $0.1 \mathrm{~g} / \mathrm{dm}^{3}$. In the case of the $\mathrm{S} 2$ electrolyte $\left(0.177 \mathrm{~g} / \mathrm{dm}^{3}\right)$, the addition of $2.0 \mathrm{~g} / \mathrm{dm}^{3}$ already decreased the Bi amount below $0.1 \mathrm{~g} / \mathrm{dm}^{3}$. In this experiment, it was possible to successfully lower the concentration of bismuth to $0.018 \mathrm{~g} / \mathrm{dm}^{3}$. The results of these purification experiments: Bi concentration in electrolytes after purification, electrolyte purification degree and the number of grams Bi removed by $1 \mathrm{~g}$ of Ba ions (purification efficiency) are presented in Table 5.

Table 5. Bi concentration in electrolytes after purification, electrolyte purification degree and the number of grams Bi removed by $1 \mathrm{~g}$ of Ba ions (purification efficiency) depending on initial Bi concentration in electrolyte and amount of barium hydroxide octahydrate additive.

\begin{tabular}{|c|c|c|c|c|}
\hline Electrolyte & $\begin{array}{c}\mathrm{Ba}(\mathrm{OH})_{2} \cdot 8 \mathrm{H}_{2} \mathrm{O} \\
\mathrm{g} / \mathrm{dm}^{3}\end{array}$ & $\begin{array}{c}\text { Bi after } \\
\text { Purification } \\
\text { Process, g/dm } 3\end{array}$ & $\begin{array}{l}\text { Electrolyte } \\
\text { Purification } \\
\text { degree, } \%\end{array}$ & $\begin{array}{c}\text { Purification } \\
\text { Efficiency, } \\
\text { g Bi/1 g Ba }\end{array}$ \\
\hline \multirow{4}{*}{ S2 } & 2 & 0.076 & 57.1 & 0.116 \\
\hline & 4 & 0.041 & 76.8 & 0.078 \\
\hline & 8 & 0.022 & 87.6 & 0.045 \\
\hline & 12 & 0.018 & 89.8 & 0.030 \\
\hline \multirow{2}{*}{ S3 } & 2 & 0.167 & 37.9 & 0.117 \\
\hline & 8 & 0.078 & 71.1 & 0.055 \\
\hline \multirow{4}{*}{ S4 } & 2 & 0.282 & 23.8 & 0.101 \\
\hline & 4 & 0.220 & 40.5 & 0.086 \\
\hline & 8 & 0.132 & 64.3 & 0.068 \\
\hline & 12 & 0.082 & 77.8 & 0.055 \\
\hline
\end{tabular}

The highest values of purification efficiency were obtained with $2 \mathrm{~g} / \mathrm{dm}^{3}$ of barium hydroxide octahydrate addition to S2, S3, S4 electrolyte: $0.116,0.117$ and $0.101 \mathrm{~g} \mathrm{Bi} / 1 \mathrm{~g} \mathrm{Ba}$, respectively. The addition of $8 \mathrm{~g} / \mathrm{dm}^{3}$ barium hydroxide octahydrate resulted in the removal of $0.045 \mathrm{~g} \mathrm{Bi} / 1 \mathrm{~g}$ Ba from the $\mathrm{S} 2$ electrolyte, similarly $0.055 \mathrm{~g} \mathrm{Bi} / 1 \mathrm{~g} \mathrm{Ba}$ (S3 electrolyte) and $0.068 \mathrm{~g} \mathrm{Bi} / 1 \mathrm{~g}$ Ba (S4 electrolyte).

As the amount of barium hydroxide octahydrate added to the electrolytes increased, a slight decrease in the purification efficiency value was observed.

Comparing this purification process to the other techniques, this method uses low energy input and less complex equipment but has never been introduced into industrial practice.

Purified industrial electrolyte by barium hydroxide octahydrate addition was used in copper electrorefining processes, which were conducted in another work in the Łukasiewicz Research Network-Institute of Non-Ferrous Metals, the Centre of Hydroelectrometallurgy [29]. The obtained results from these electrorefining tests [29] showed that it is possible to conduct electrorefining processes with purified electrolytes by the method described in this article without adversely affecting the process indicators and quality of the copper cathode.

\section{Conclusions}

Laboratory tests of the purification of industrial copper electrolyte from bismuth impurity below $0.1 \mathrm{~g} / \mathrm{dm}^{3}$ were conducted. The agents with adsorbing effect were selected: barium hydroxide octahydrate, strontium carbonate, barium carbonate, barium sulfate and lead sulfate. The dependence of electrolyte purification degree on initial bismuth 
concentration in electrolyte, process time, temperature, type and amount of selected agents were investigated. After the conducted experiments, it can be concluded that:

(1) The electrolyte purification degree depends on the initial Bi concentration in copper electrolyte, on time and temperature as well as on the type and amount of the bismuthlowering agent.

(2) It is possible to purify copper electrolyte from bismuth impurity using barium hydroxide octahydrate, strontium carbonate, barium carbonate at $60{ }^{\circ} \mathrm{C}$ for $1 \mathrm{~h}$. This temperature revealed the most satisfactory results and the highest electrolyte purification degree in the case of these three agents added.

(3) The conducted experiments showed that the addition of compounds in the form of sulfates to the copper electrolyte did not reduce the bismuth concentration because the efficiency of the purification process is much higher when the agents are added in the form of carbonates or hydroxides.

(4) It is achievable to reduce Bi concentrations below $0.1 \mathrm{~g} / \mathrm{dm}^{3}$ and part of the antimony in the electrolyte by using barium hydroxide octahydrate, strontium carbonate and barium carbonate under appropriate conditions of the purification process.

(5) Extending the electrolyte purification process time may cause dissolution of bismuth from the resulting precipitate and increase of bismuth concentration in the electrolyte.

(6) Comparing the purification method used in this work to the techniques, such as ion exchange, solvent extraction, molecular recognition technology or others, this method uses low energy input and less complex equipment. The purification process is based on the addition of a specified amount of selected agents under appropriate process conditions.

Author Contributions: Conceptualization, P.K.; methodology, P.K. and D.K.; investigation, P.K.; writing-original draft preparation, P.K.; writing—review and editing, P.K., D.K., M.C., M.D. and K.L.-S.; visualization, P.K.; supervision, D.K., M.C., M.D. and K.L.-S.; funding acquisition, K.L.-S. All authors have read and agreed to the published version of the manuscript.

Funding: This research was funded by the Polish Ministry of Science and Higher Education under the project registration codes 0332030008 and 0334328001.

Data Availability Statement: Not applicable.

Acknowledgments: We would like to thank the Łukasiewicz Research Network-Institute of NonFerrous Metals, the Centre of Analytical Chemistry for analysis of the samples.

Conflicts of Interest: The authors declare no conflict of interest. The funders had no role in the design of the study; in the collection, analyses, or interpretation of data; in the writing of the manuscript, or in the decision to publish the results.

\section{References}

1. Artzer, A.; Moats, M.; Bender, J. Removal of antimony and bismuth from copper electrorefining electrolyte: Part I-A Review. JOM 2018, 70, 2033-2040. [CrossRef]

2. Schlesinger, M.E.; King, M.J.; Sole, K.C.; Davenport, W.G. Electrolytic Refining. In Extractive Metallurgy of Copper, 5th ed.; Schlesinger, M.E., Sole, K.C., Davenport, W.G., Eds.; Elsevier: New York, NY, USA, 2011; pp. 251-280.

3. Popov, K.; Djokić, S.S.; Grgur, B.N. Electrorefining. In Fundamental Aspects of Electrometallurgy; Kluwer Academic Publisher: New York, NY, USA; Boston, MA, USA; Dordrecht, The Netherlands; London, UK; Moscow, Russia, 2002; pp. 181-189.

4. Moats, M.; Wang, S.; Filzwieser, A.; Siegmund, A.; Davenport, W.; Robinson, T. Survey of copper electrorefining operations. In Proceedings of the 9th International Copper Conference, Kobe, Japan, 13-16 November 2016.

5. Hyvärinen, O.V.J. Process for Selective Removal of Bismuth and Antimony from an Electrolyte, Especially in Electrolytic Refining of Copper. U.S. Patent 4,157,946, 12 June 1979.

6. González de las Torres, A.I.; Moats, M.S.; Ríos, G.; Rodríguez Almansa, A.; Sánchez-Rodas, D. Removal of Sb impurities in copper electrolyte and evaluation of As and Fe species in an electrorefining plant. Metals 2021, 11, 902. [CrossRef]

7. Ruiz, I.; Rios, G.; Arbizu, C.; Burke, I.; Hanschke, U. Pilot tests on bismuth and antimony removal from electrolyte at Atlantic Copper refinery. In Proceedings of the European Metallurgical Conference, Weimar, Germany, 23-26 June 2013.

8. McKevitt, B.; Dreisinger, D. A comparison of various ion exchange resins for the removal of ferric ions from copper electrowinning electrolyte solutions Part II: Electrolytes containing antimony and bismuth. Hydrometallurgy 2009, 98, 122-127. [CrossRef] 
9. Arroyo-Torralvo, F.; Rodríguez-Almansa, A.; Ruiz, I.; González, I.; Ríos, G.; Fernández-Pereira, C.; Vilches-Arenas, L.F. Optimizing operating conditions in an ion-exchange column treatment applied to the removal of $\mathrm{Sb}$ and $\mathrm{Bi}$ impurities from an electrolyte of a copper electro-refining plant. Hydrometallurgy 2017, 171, 285. [CrossRef]

10. Artzer, A.; Moats, M.; Bender, J. Removal of Antimony and Bismuth from Copper Electrorefining Electrolyte: Part II-An Investigation of Two Proprietary Solvent Extraction Extractants. JOM 2018, 70, 2856-2863. [CrossRef]

11. Navarro, P.; Simpson, J.; Alguacil, F.J. Removal of antimony (III) from copper in sulphuric acid solutions by solvent extraction with LIX 1104SM. Hydrometallurgy 1999, 53, 121-131. [CrossRef]

12. Krishnan, S.; Zulkapli, N.S.; Kamyab, H.; Taib, S.M.; Din, M.F.B.M.; Majid, Z.A.; Chaiprapat, S.; Kenzo, I.; Ichikawa, Y.; Nasrullah, M.; et al. Current technologies for recovery of metals from industrial wastes: An overview. Environ. Technol. Innov. 2021, 22, 101525. [CrossRef]

13. Thanu, V.R.C.; Jayakumar, M. Electrochemical recovery of antimony and bismuth from spent electrolytes. Sep. Purif. Technol. 2019, 235, 116169. [CrossRef]

14. Navarro, L.; Morris, T.; Read, W. Copper Refining Electrolyte Purification by the Use of Molecular Recognition Technology (MRT) for Bismuth Removal. In T.T. Chen Honorary Symposium on Hydrometallurgy, Electrometallurgy and Materials Characterization; Wang, S., Dutrizac, J.E., Free, M.L., Hwang, J.I., Kim, D., Eds.; TMS: Orlando, FL, USA, 2012; pp. 141-149.

15. Izatt, R.M.; Izatt, S.R.; Izatt, N.E.; Krakowiak, K.E.; Bruening, R.L.; Navarro, L. Industrial applications of molecular recognition technology to separations of platinum group metals and selective removal of metal impurities from process streams. Green Chem. 2015, 17, 2236-2245. [CrossRef]

16. Komulainen, T.; Doyle, F.J., III; Rantala, A.; Jämsä-Jounela, S.-L. Control of an industrial copper solvent extraction process. J Process Control 2009, 19, 2-15. [CrossRef]

17. Nagai, T. Purification of Copper Electrolyte by Solvent Extraction and Ion-Exchange Techniques. Miner. Process. Extr. Metall. Rev. 1997, 17, 143-168. [CrossRef]

18. Perez, I.D.; Botelho, A.B., Jr.; Aliprandini, P.; Espinosa, D.C.R. Copper recovery from nickel laterite with high-iron content: A continuous process from mining waste. Can. J. Chem. Eng. 2019, 98, 957-968. [CrossRef]

19. Junior, A.B.B.; Espinosa, D.C.R.; Dreisinger, D.; Tenório, J.A.S. Recovery of Nickel and Cobalt from Nickel Laterite Leach Solution Using Chelating Resins and Pre-Reducing Process. Can. J. Chem. Eng. 2018, 97, 1-10.

20. International Copper Study Group. Available online: http://www.icsg.org/index.php/component/jdownloads/finish/170/2876 (accessed on 23 November 2021).

21. Noguchi, F.; Nakamura, T.; Ueda, Y. Behaviour of anode impurities in copper electrorefining. Effect of bismuth, arsenic, antimony and oxygen in copper anode. J. Min. Mater. Process. Inst. Jpn. 1989, 105, 321-327.

22. Chen, T.T.; Dutrizac, J.E. A Mineralogical Study of the Effect of the Lead Content of Copper Anodes on the Dissolution of Arsenic, Antimony and Bismuth during Copper Electrorefining. Can. Metall. Q. 2003, 42, 421-432. [CrossRef]

23. Wang, X.; Chen, Q.; Yin, Z.; Wang, M.; Xiao, B.; Zhang, F. Homogeneous precipitation of As, Sb, and Bi impurities in copper electrolyte during electrorefining. Hydrometallurgy 2011, 105, 355-358. [CrossRef]

24. Xiao, F.; Mao, J.; Cao, D.; Shen, X.; Volinsky, A.A. The role of trivalent arsenic in removal of antimony and bismuth impurities from copper electrolytes. Hydrometallurgy 2012, 125-126, 76-80. [CrossRef]

25. Wang, X.; Chen, Q.; Yin, Z.; Zhang, P.; Long, Z.; Su, Z. Removal of impurities from copper electrolyte with adsorbent containing antimony. Hydrometallurgy 2003, 69, 39-44. [CrossRef]

26. Wang, X.-W.; Chen, Q.-Y.; Yin, Z.-L.; Wang, M.Y.; Tang, F. The role of arsenic in the homogeneous precipitation of As, Sb and Bi impurities in copper electrolyte. Hydrometallurgy 2011, 108, 199-204. [CrossRef]

27. Schulze, R. Process for Preventing Supersaturation of Electrolytes with Arsenic, Antimony and Bismuth. U.S. Patent 3,696,012, 3 October 1972.

28. Navarro, P.; Alguacil, F.J. Adsorption of antimony and arsenic from a copper electrorefining solution onto activated carbon Hydrometallurgy 2002, 66, 101-105. [CrossRef]

29. Kowalik, P.; Kopyto, D.; Chmielarz, A.; Leszczyńska-Sejda, K. Bismuth Influence of the Quality Copper Cathode in Electrorefining Process. In Proceedings of the 11th European Metallurgical Conference, Salzburg, Austria, 27-30 June 2021; pp. 519-532, ISBN 978-3-940276-96-4 